\title{
On the occurrence of Antillesoma antillarum (Grube, 1858) (Sipuncula, Antillesomatidae) on the south-central part of the Colombian Caribbean coast
}

\author{
Jorge A. Quirós-Rodríguez ${ }^{1 *}$, Gilmar Santafé-Patiño ${ }^{1}$, Carlos Nisperuza-Pérez² \\ 1 Grupo de Investigación Química de los Productos Naturales (PRONAT), Universidad de Córdoba, Montería, Colombia •JAQ: alexander_quiroz@ \\ hotmail.com (1) https://orcid.org/0000-0003-2618-3282 • GSP: gsantafe@correo.unicordoba.edu.co @ https://orcid.org/0000-0002-9235-3844 \\ 2 Grupo de Investigación en Biotecnología (GRUBIODEQ), Universidad de Córdoba, Montería, Colombia • CNP: carlosnisperuzap@correo. \\ unicordoba.edu.co (1) https://orcid.org/0000-0002-2312-4677 \\ * Corresponding author
}

\begin{abstract}
We document here the first confirmed report of the sipunculan worm Antillesoma antillarum (Grube, 1858) based on freshly collected, taxonomically verified specimens from the south-central Colombian Caribbean coast. This species was encountered on massive coralline rocks, coral rubble, and coral boulder at San Antero. We briefly describe and illustrate this species and provide notes on its distribution, ecology, and habitat.
\end{abstract}

Keywords

Cryptobiota, geographical distribution, hard substrata, marine environment, sipunculan worm

Academic editor: Luis Felipe Skinner | Received 18 May 2021 | Accepted 9 August 2021 | Published 2 September 2021

Citation: Quirós-Rodríguez JA, Santafé-Patiño G, Nisperuza-PérezC (2021) On the occurrence of Antillesoma antillarum (Grube, 1858) (Sipuncula, Antillesomatidae) on the south-central part of the Colombian Caribbean coast. Check List 17 (5): 1199-1204. https://doi.org/10.15560/17.5.1199

\section{Introduction}

The sipunculans, commonly known as the peanut worms or star worms (Schulze et al. 2019), are a small group of bilaterally symmetrical, coelomate and non-segmented marine worm (Murina 1984; Cutler 1994) considered close to the annelid group (Staton 2003; Struck et al. 2007; Dordel et al. 2010). The number of recognized species ranges from a systematic compilation of approximately 320 species (Stephen and Edmonds 1972) to a revised number of 150 species (Cutler 1994). The body is formed in two main parts: a larger trunk without segmentation and a retractable introvert, with a tentacular arrangement at the most distal part, either arranged in a circle around the mouth or in a horseshoe shape around the chemosensory nuchal organ. This tentacular crown is more or less developed depending on the taxonomic group (Spongberg 2006; Schulze and Kawauchi 2021). The introvert is often adorned with shields, papillae, and proteinaceous hooks. The remainder of the body wall may be smooth or covered with papillae of various shapes and sizes. Some species, particularly in the genera Aspidosiphon Diesing, 1851 and Cloeosiphon Grube, 1868, have proteinaceous shields at the anterior and sometimes at the posterior end. Antillesoma antillarum (Grube, 1858) have some purple pigment on their tentacles or at the tentacle base (Rice 
1975; Cutler 1994; Adrianov et al. 2006; Adrianov and Maiorova 2012; Schulze and Kawauchi 2021).

Despite their high abundance, sipunculans are often neglected in fauna studies, mainly due to their cryptic habitats and the inability to identify species, which can be challenging for non-experts. Peanut worms have been reported in sand and mud, cracks in or under rocks, burrows in coral or other rocks, and in a variety of abandoned molluscs shells (Schulze 2005; Kedra and Murina 2007; Silvia-Morales et al. 2019). Small sand-filled crevices between the rocks have been reported to be often inhabited by Themiste Gray, 1828, Antillesoma Stephen \& Edmonds, 1972, and some Golfingia Lankester, 1885 (Cutler et al. 1984). They are considered ecologically important in the process of dissolving rocks and formation and degeneration of coral reefs, as well as an ecological indicator for environmental monitoring (Glynn 1997; Fonseca et al. 2006; Antonelli et al. 2015). Recent phylogenetic hypotheses have suggested their placement with Annelida based entirely on molecular analyses (Struck et al. 2007; Dordel et al. 2010; Lemer et al. 2015). However, this placement is not supported by analyses based on combined data from extant taxa and fossil (Parry et al. 2016). The fossil record, although sparse, shows a remarkable conservation of the basic sipunculan morphology since the Cambrian (Maxmen et al. 2003; Huang et al. 2004; Muir and Botting 2007).

The first record of Antillesoma antillarum reported from Costa Rican waters was collected from Puntarenas and described by Grube (1858). It has been reported in the western Atlantic and the Caribbean from Florida to Brazil. On the coast of Venezuela, it has been recorded from the islands of Cabagua, Los Roques Archipelago National Park, and the Gulf of Cariaco (Cutler and Cutler 1989; Díaz 2011). To our knowledge, little information is available on sipunculans of the Colombian Caribbean. Nevertheless, one publication about this group associated with dead coral skeletons exists; it mentions A. antillarum within skeletons of Pseudodiploria strigosa (Dana, 1846) and Orbicella annularis (Ellis \& Solander, 1786) in the Santa Marta region (Gómez et al. 2013). Despite the distribution of A. antillarum in the northern Colombian Caribbean, we report here the first confirmed presence of this species in the central and southern Colombian region based on our morphological study of recently collected specimens.

\section{Methods}

Sampling localities are within the San Antero region, on the south-central Colombian Caribbean coast (Fig. 1). The region is characterized as tropical with an average annual temperature of $28^{\circ} \mathrm{C}$, relative humidity of $84 \%$ and average annual precipitation of $1,337 \mathrm{~mm}$ per year (Rangel-Ch and Arellano 2010) and is influenced by the Alisios winds from the northeast and oscillations of the intertropical convergence zone (ITCZ) that regulate the two main climatic seasons that occur in the year (Patiño

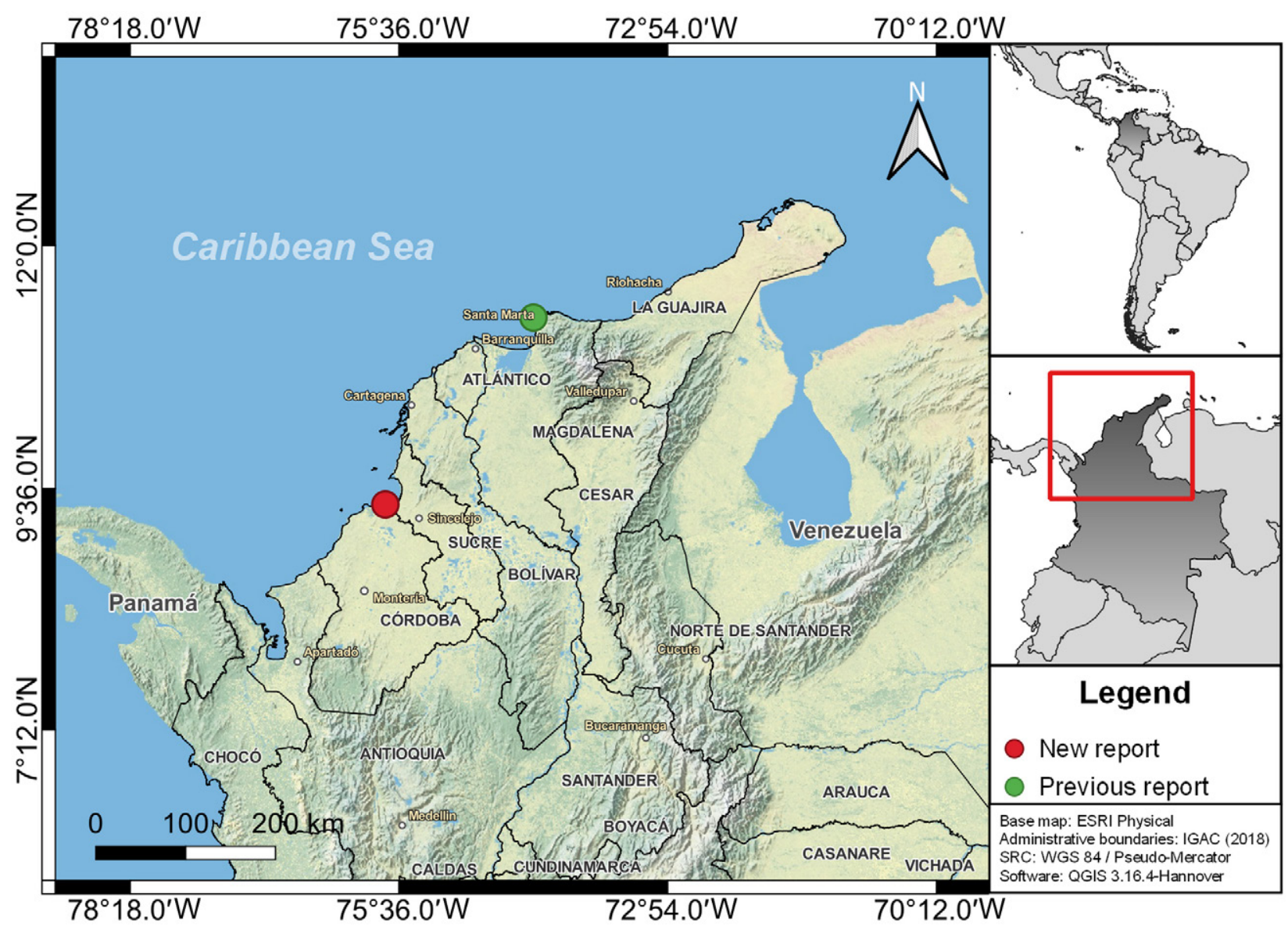

Figure 1. Distribution of Antillesoma antillarum from the Colombian Caribbean: green circle = previous report; red circle = new report. 

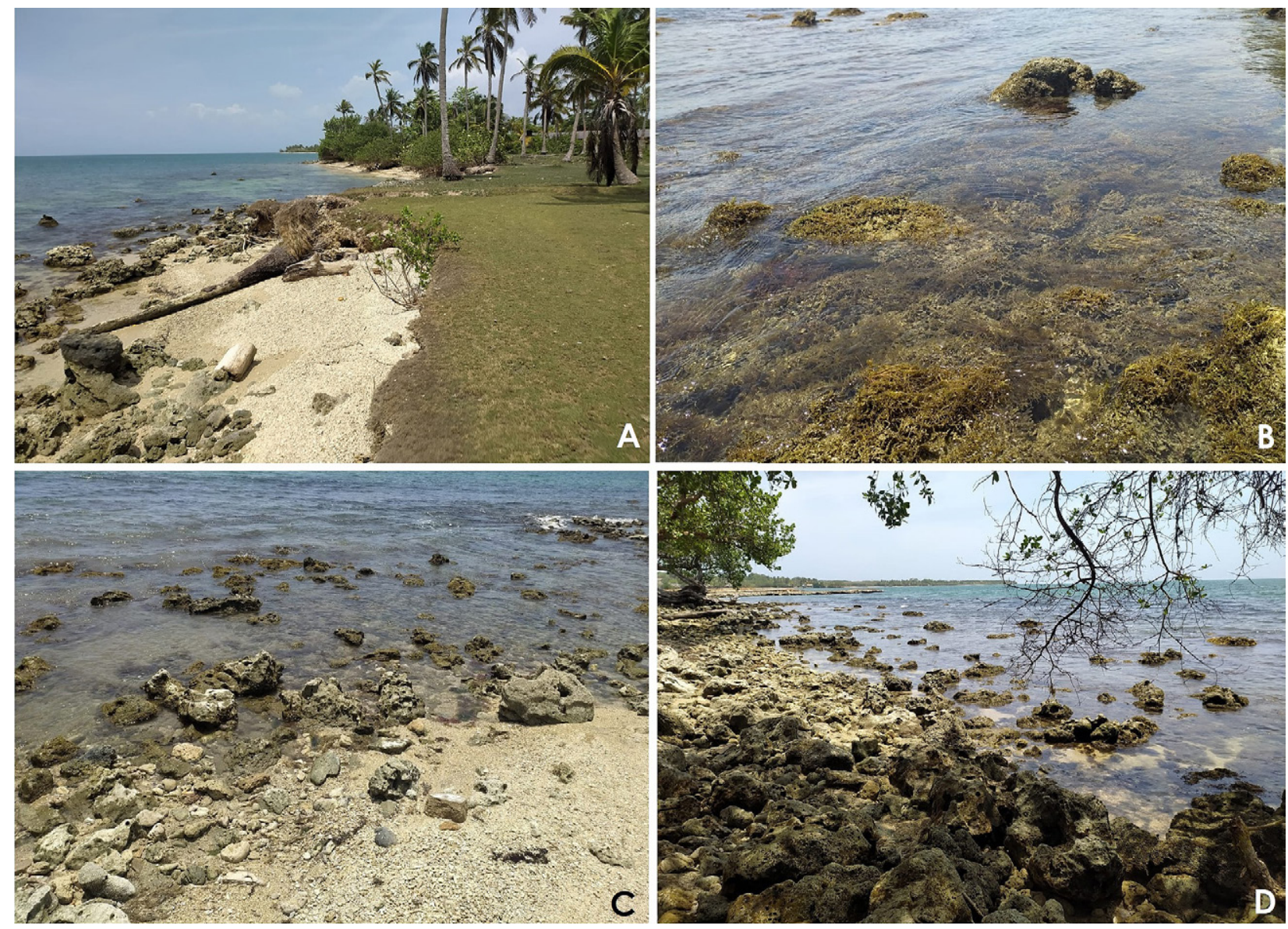

Figure 2. Habitats of Antillesoma antillarum in San Antero coast, Córdoba, Colombian Caribbean. A, B. Punta Bello habitat, with emphasis on massive coral rocks and macroalgae. C, D. Punta Bolívar habitat, with emphasis on coral rubble and coral boulders.

and Flórez 1993). We sampled specimens at Punta Bello and Punta Bolívar from February and March 2019. At Punta Bello there are massive coral rocks and also sponges and macroalgae associated with these rocks. While at Punta Bolívar, coral rubble, coral boulders, and isolated rocks are form the coastline (Fig. 2).

We collected specimens of $A$. antillarum by hand. The specimens were relaxed with menthol and fixed with $10 \%$ seawater formalin and later transferred to $70 \%$ alcohol for preservation. Length measured from the anterior (introvert) to posterior (end of trunk) and trunk width in mm was taken in the Microscopy Laboratory of the University of Córdoba, with an HD digital camera attached to the Carl Zeiss Axiostar stereomicroscope. Images were assembled using the image stacking software AxioVision Carl Zeiss (Rel.4.8.2. SP3).

Distribution maps were made using QGIS 3.16.4. LTR. Longitude and latitude were obtained from the implementation of primary and secondary information. Localities of specimens were plotted on a global land projection using Environmental Systems Research Institute (ESRI).

\section{Results}

The records below are the first of this peanut worm species from Punta Bolívar and Punta Bello, department of
Córdoba, and represent the second time that $A$. antillarum has been reported from Colombia.

Phylum Sipuncula Stephen, 1964

Family Antillesomatidae Kawauchi, Sharma \& Giribet, 2012

Genus Antillesoma Stephen \& Edmonds, 1972

\section{Antillesoma antillarum (Grube, 1858)}

Figure 3

Newrecords.COLOMBIA-Córdoba•SanAntero; Punta

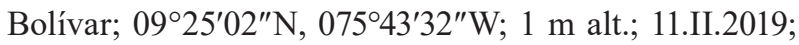
Jorge A. Quirós Rodríguez leg.; 2 specimens, CZUCAN0028 - San Antero; Punta Bello; 09²5'11"N, 075 44'28"W; 1.5 m alt.; 14.III.2019; Carlos A. Nisperuza Pérez leg.; 7 specimens, CZUC-AN0029.

Identification. The external anatomy and characters of the individuals examined agree with the descriptions provided by Stephen and Edmonds (1972) and Cutler (1994). Voucher material of A. antillarum was deposited in the Zoological Collection of the University of Córdoba (CZUC-AN).

This species undoubtedly belongs to the monotypic genus Antillesoma, which has a trunk 16-35 mm long and a maximum width of $11 \mathrm{~mm}$ (Fig. 3A). There is a large number of digitiform tentacles ( $>40$ in adults) with violet strips and patches (brown in preserved specimens) 


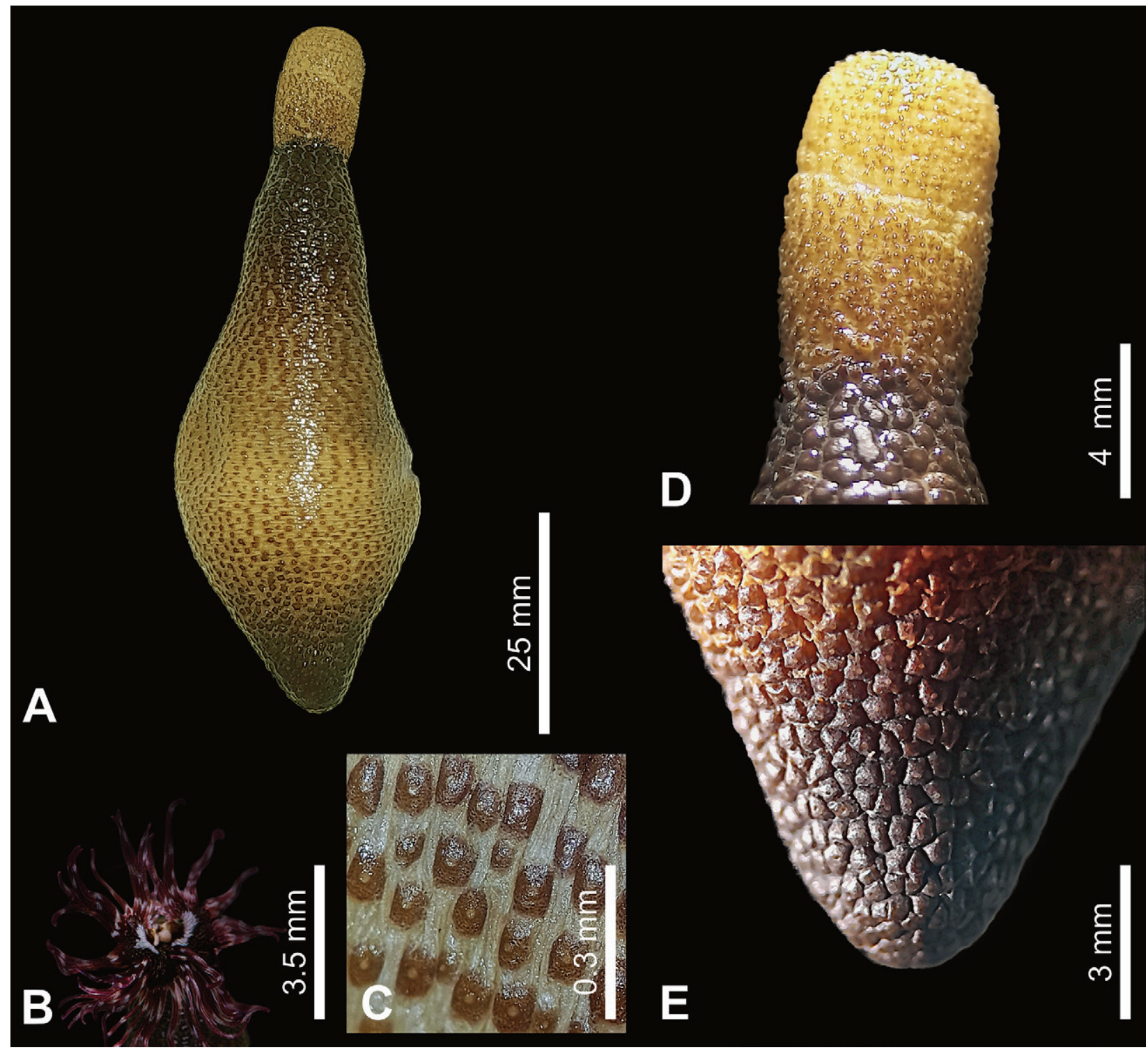

Figure 3. Antillesoma antillarum (Grube, 1858) A. External view. B. Digitiform tentacles (live specimen). C. Papillae in the middle part of the trunk. D. Papillae from anterior part of the trunk. E. Papillae at the trunk end.

surrounding the nuchal organ (Fig. 3B). The introvert is shorter than the trunk and without hooks. The anterior and posterior trunk is dark brown, and the middle region is light-colored and with small papillae (Fig. 3C). The trunk is usually covered with prominent, hemispherical papillae, which are often brown to dark red-brown. Trunk papillae are usually largest at the anterior and posterior ends (Fig. 3D, E).

Habitat. This is a common species found in hard substrata, occurring intertidally $(1 \mathrm{~m})$ in rock crevices, massive coralline rocks, coral rubble, and coral boulders. We found this species associated with a variety of habitats: the sponges Tedania (Tedania) ignis (Duchassaing \& Michelotti, 1864), Amphimedon viridis Duchassaing \& Michelotti, and Neopetrosia carbonaria (Lamarck, 1814) and the macroalgae Gracilaria mammillaris (Montagne) M. Howe, 1918, G. cervicornis (Turner) J. Agardh, 1852, and Alsidium triquetrum (S.G. Gmelin) Trevisan, 1845).

Previous records in Colombia. Antillesoma antillarum was collected from nearby coral reef areas off Santa Marta (Magdalena) (Gómez et al. 2013).

\section{Discussion}

Antillesoma antillarum is a common, worldwide species in hard substrata (Hutching 1986; Peyrot-Clausade et al. 1992; Glynn 1997). Despite it being a dominant sipunculan species inhabiting of both live and dead portions of coral skeletons, there are just a few records of the species from around the Colombian Caribbean (Gómez et al. 2013; Quiroz-Ruiz and Londoño-Mesa 2015). In the study area, we found it in hard substrata, occurring in massive coralline rocks, crevices, and coral rubble (Cutler 1994; Glynn 1997; Gómez et al. 2013). Other authors have reviewed the ecological importance of this species in coral reef environments because of this species' capacity to degrade calcium carbonate; thus, it is an important component in bioerosion (Hutchings 1986; Peyrot-Clausade and Brunel 1990; Moreno-Forero et al. 1998; Gómez et al. 2013). 
According to several authors, the shallow waters of the northern Colombian Caribbean, and especially embayments, are inhabited by many sipunculid worms associated with dead coral skeletons such as Aspidosiphon elegans (Chamiso \& Eysenhardt, 1891), A. fischeri ten Broeke, 1925, A. parvulus Gerould, 1913, A. steenstrupii (Diesing, 1859), Lithacrosiphon cristatus (Sluiter, 1902), Phascolosoma nigrescens (Keferstein, 1865), $P$. perlucens (Baird, 1868), and A. antillarum; all of these species belong to cooler-waters elements with input from inland waters and sediments from the Ciénaga Grande de Santa Marta, the Magdalena River and a number of rivers from the Sierra Nevada de Santa Marta (Franco 2005; Árevalo-Martínez and Franco-Herrera 2008). However, A. antillarum is also adapted to warm waters along the San Antero coast and from the Sinú River. Further field investigations are likely to reveal the existence of additional sipunculan species in and around the south-central part of the Colombian Caribbean.

The paucity of $A$. antillarum records on the south-central Colombian Caribbean coast may be related to the lack of suitable coral habitats for these worms. It remains to be investigated if this region of coast has a lower availability of this type of habitats compared to other areas of the world, or if this ecological niche is more efficiently occupied by other faunal competitors, such as crustaceans, echinoderms, and mollusks. Furthermore, the type of rock morphology, which influences the establishment of the cryptobiota on hard substrates, could also be a factor related to the low number of specimens found in our study. Massive coralline rocks tend to have a smaller of surface area of dead corals and, thus, support fewer organisms than branched forms (Moreno-Forero et al. 1998; Gómez et al. 2013). Fewer specimens of A. antillarum would therefore be expected in the San Antero where the intertidal zone is mostly composed of massive coralline rocks.

Our material of $A$. antillarum is the first from the Córdoba region. The closest previously known occurrence is about $400 \mathrm{~km}$ to the northeast in Santa Marta. The taxonomy, ecology, and distribution of sipunculans in the Colombian Caribbean needs additional study, and the findings of this study will lay the foundation for future monitoring that promotes the management and conservation of ecosystems and marine resources.

\section{Acknowledgements}

We thank the personnel of the Zoology Laboratory of the University of Córdoba, as well as the editor and two anonymous reviewers who provided constructive criticism that helped to improve this article. This work was funded by the vice-rectory of research and extension of the University of Córdoba, FCB-02-19.

\section{References}

Adrianov AV, Malakhov VV, Maiorova AS (2006) Development of the Tentacular Apparatus in Sipunculans (Sipuncula): I. Thy- sanocardia nigra (Ikeda,1904) and Themiste pyroides (Chamberlin, 1920). Journal of Morphology 267: 569-583. https://doi. org/10.1002/jmor. 10423

Adrianov AV, Maiorova AS (2012) Peanut worms of the phylum Sipuncula from the Nha Trang Bay (South China Sea) with a key to species. Zootaxa 3166: 41-58. https://doi.org/10.11646/zootaxa. 3166.1 .3

Antonelli F, Sacco-Perasso C, Ricci S, Davidde-Petriaggi B (2015) Impact of the sipunculan Aspidosiphon muelleri Diesing, 1851 on calcareous underwater Cultural Heritage. International Biodeterioration \& Biodegradation 100:133-139. https://doi.org/10.1016/j. ibiod.2015.02.025

Árevalo-Martínez DL, Franco-Herrera A (2008) Características oceanográficas de la surgencia frente a la ensenada de Gaira, departamento de Magdalena, época seca menor de 2006. Boletín de Investigaciones Marinas y Costeras 37 (2): 131-162.

Cutler EB (1994) The Sipuncula: their systematics, biology and evolution. Cornell University Press, Ithaca, New York, USA, 453 pp.

Cutler EB, Cutler NJ (1989) A revision of the genus Aspidosiphon (Sipuncula: Aspidosiphonidae). Proceedings of the Biological Society of Washington 102 (4): 826-365.

Cutler EB, Cutler NJ, Nishikawa T (1984) The sipuncula of Japan: their systematics and distribution. Publications of the Seto Marine Biological Laboratory 29 (4-6): 249-322. https://doi.org/10.5134/ 176092

Díaz O (2011) Estado del conocimiento de los sipuncúlidos (Sipunculida) del golfo de Cariaco, Venezuela. Boletín del Instituto Oceanográfico de Venezuela 50 (2): 167-171.

Dordel J, Fisse F, Purschke G, Struck TH (2010) Phylogenetic position of Sipuncula derived from multi-gene and phylogenomic data and its implication for the evolution of segmentation. Journal of Zoological Systematics and Evolutionary Research 48 (3): 197-207. https://doi.org/10.1111/j.1439-0469.2010.00567.x

Fonseca AC, Dean HK, Cortés J (2006) Non-colonial coral macroborers as indicators of coral reef status in the south Pacific of Costa Rica. Revista de Biología Tropical 54 (1): 101-115. https:// doi.org/10.15517/rbt.v54i1.13977

Franco A (2005) Oceanografía de la ensenada de Gaira: El Rodadero más que un centro turístico en el Caribe colombiano. Universidad Jorge Tadeo Lozano, Bogotá, Colombia, 56 pp.

Glynn PW (1997) Bioerosion and coral reef growth: a dynamic balance. In: Birkeland C (Ed.) Life and death of coral reefs. Chapman and Hall, London, United Kingdom, 68-95.

Gómez CE, Ardila NE, Sanjuan-Muñoz A (2013) Sipunculans associated with dead coral skeletons in the Santa Marta region of the Colombia, south-western Caribbean. Journal of the Marine Biological Association of the United Kingdom 93 (7): 1785-1793. https://doi.org/10.1017/s002531541300043x

Grube E (1858) Annulata Öerstediana: Enumeratio Annulatorum quae in itinere der Indiam occidentalem et Americam centralem annis 1845-1848 suscept legit cl. A. S. Oersted, adjectis speciebus nonnullis a cl. H. Kröyer in itinere ad Americam meridionalem collectis. Videnskabelige Meddelelser fra Dansk Naturhistorisk Forening i Kjöbenhaven Nr. 1-4: 105-120.

Huang D, Chen J, Vannier J, Saiz-Salinas JI (2004) Early Cambrian sipunculan worms from southwest China. Proceedings of the Royal Society of London, Series B 271 (1549): 1671. https://doi. org/10.1098/rspb.2004.2774

Hutchings PA (1986) Biological destruction of coral reef: a review. Coral Reef 4 (4): 239-252. https://doi.org/10.1007/BF00298083

Kędra M, Murina GV (2007) The sipunculan fauna of Svalbard. Polar Research 26 (1): 37-47. https://doi.org/10.3402/polar.v26i1.6205

Lemer S, Kawauchi GY, Andrade SCS, González VL, Boyle MJ, Giribet G (2015) Re-evaluating the phylogeny of Sipuncula through transcriptomics. Molecular Phylogenetics and Evolution 83: 174 183. https://doi.org/10.1016/j.ympev.2014.10.019

Maxmen AB, King EF, Cutler EB, Giribet G (2003) Evolutionary rela- 
tionships within protostome phylum Sipuncula: a molecular analysis of ribosomal genes and histone $\mathrm{H}_{3}$ sequence data. Molecular Phylogenetic and Evolution 27 (3): 489-503. https://doi.org/10. 1016/S1055-7903(02)00443-8

Moreno-Forero SK, Navas GR, Solano OD (1998) Cryptobiota associated to dead Acropora palmata (Scleractinia: Acroporidae) coral, Isla Grande, Colombian Caribbean. Revista de Biología Tropical 46 (2): 229-236. https://doi.org/10.15517/rbt.v46i2.19432

Muir LA, Botting JP (2007) A lower carboniferous sipunculan from the Granton Shrimp Bed, Edinburgh. Scottish Journal of Geology 43(1): 51-56. https://doi.org/10.1144/sjg43010051

Murina GV (1984) Ecology of Sipuncula. Marine Ecology Progress Series 17: 1-7.

Parry LA, Edgecombe GD, Eibye-Jacobsen D, Vinther J (2016) The impact of fossil data on annelid phylogeny inferred from discrete morphological characters. Proceedings of the Royal Society B: Biological Sciences 283 (1837): 20161378. https://doi.org/10.1098/ rspb.2016.1378

Patiño F, Flórez F (1993) Ecología marina del golfo de Morrosquillo. Universidad Nacional de Colombia, Fondo FEN, Bogotá, Colombia, 109 pp.

Peyrot-Clausade M, Brunel JF (1990) Distribution patterns of macroboring organisms on Tuléar reef flats (SW Madagascar). Marine Ecology Progress Series 61: 133-144.

Peyrot-Clausade M, Hutchings P, Richard G (1992) Temporal variations of macroborers in massive Porites lobata on Moorea, French Polynesia. Coral Reef 11: 161-166. https://doi.org/10.1007/ bf00255471

Quiroz-Ruiz MM, Londoño-Mesa MH (2015) Sipúnculos (Sipuncula) del gran Caribe: lista de especie y bibliografía. Boletín de Investigaciones Marinas y Costeras 44 (2): 327-342.

Rangel-Ch JO, Arellano H (2010) Bosques de Polylepis: un tipo de vegetación Condenado a la Extinción. In: Rangel-Ch JO (Ed.) Colombia: Diversidad Biótica X. Instituto de Ciencias Naturales-Instituto Alexander Von Humboldt, Bogotá, Colombia, 443-478.
Rice ME (1975) Survey of the Sipuncula of the coral and beach-rock communities of the Caribbean Sea. In: Rice ME, Todorovic M (Eds.) Proceeding of the International Symposium on the Biology of Sipuncula and Echiura. Naucno Delo Press, Belgrade, Serbia, 35-49.

Schulze A (2005) Sipuncula (Peanut Worms) from Bocas del Toro, Panamá. Caribbean Journal of Sciences 41 (3): 523-527.

Schulze A, Kawauchi GY (2021) How many sipunculan species are hiding in our oceans? Diversity 13 (2): 43. https://doi.org/10.3390/ d13020043

Schulze A, Boyle MJ, Kawauchi GY (2019) Amphinomida/Sipuncula. In: Purschke G, Böggemann M, Westheide W (Eds.) Handbook of zoology: Annelida, basal groups and Pleistoannelida, Sedentaria I. DeGruyter GmbH \& Co. KG, Berlin, Germany, 177201. https://doi.org/10.1515/9783110291582-006

Silva-Morales I, López-Aquino MJ, Islas-Villanueva V, Ruiz-Escobar F, Bastida-Zavala JR (2019) Morphological and molecular differences between the Amphiamerican populations of Antillesoma (Sipuncula: Antillesomatidae), with the description of a new species. Revista de Biología Tropical 67 (S5): S101-S109. https://doi. org/10.15517/rbt.v67is5.38934

Spongberg AL (2006) PCB concentrations in intertidal sipunculan (Phylum Sipuncula) marine worms from the Pacific coast of Costa Rica. Revista de Biología Tropical 54 (Suppl. 1): 27-33. https:// doi.org/10.15517/rbt.v54i1.26836

Staton JL (2003) Phylogenetic analysis of the mitochondrial cytochrome $\mathrm{c}$ oxidase subunit 1 gene from 13 sipunculan genera: intra- and interphylum relationships. Invertebrate Biology 122 (3): 252-264. https://doi.org/10.1111/j.1744-7410.2003.tb00089.x

Stephen AC, Edmonds SJ (1972) The phyla Sipuncula and Echiura. British Museum Press, London, United Kingdom, 528 pp.

Struck TH, Schult N, Kusen T, Hickman E, Bleidorn C, McHugh D, Halanych KM (2007) Annelid phylogeny and the status of Sipuncula and Echiura. BMC Evolutionary Biology 7: e57. https://doi. org/10.1186/1471-2148-7-57 